\title{
MAPPING GENDER: FEMINIST CARTOGRAPHIES IN KATE CHOPIN'S “REGIONALIST” STORIES
}

\author{
Kari Meyers Skredsvig
}

\begin{abstract}
RESUMEN
En este artículo -el cuarto de una serie de artículos que gira alrededor de las relaciones entre las mujeres y el espacio literario-, se examina las maneras en que las coyunturas de literatura, geografía y género iluminan de forma novedosa los relatos "regionalistas" de Kate Chopin, una autora de los E.E.U.U. del siglo XIX. En el proceso de examinar tanto la vida de la autora como su obra en términos de "geografías de identidad" y la construcción de una subjetividad femenina, los dos cuentos aquí analizados adquieren una significancia mucho más allá de su superficie "costumbrista" y se transforman -igual que las historias de las mujeres que las protagonizan- en sitios de lucha. Mientras que las lecturas tradicionales de la ficción "costumbrista" de Chopin producen historias agradables que reafirman limitaciones culturales, el análisis desde una perspectiva de geografías feministas resalta las maneras en que Chopin reta las limitaciones literarias y el reducido espacio asignado a la mujer en su propio contexto.
\end{abstract}

\begin{abstract}
In this article -the fourth in a series which examines relationships between women and literary space- I examine ways in which conjunctures of literature, geography, and gender shed new light on nineteenthcentury U.S. author Kate Chopin's "regionalist" stories. In the process of examining her life and her work in terms of "geographics of identity" and gendered subjectivity, the two representative short stories analyzed here take on a significance far beyond their "local color" surface and themselves become -like the stories of their female protagonists- sites of struggle. While traditional readings of Chopin's "regionalist" fiction yield mildly intriguing tales which reaffirm cultural boundaries, analysis from a perspective of feminist geographies highlights Chopin's challenges to the circumscribed literary and gender spheres of her own context.
\end{abstract}

\section{Introduction}

The merger of literature, geography, and gender may strike some readers as unlikely, perhaps even dubitable. Certainly today's academic emphasis on interdisciplinarity is producing some surprising innovations, and in so doing, is concomitantly enriching the areas it touches, whether traditional or newly created fields of inquiry. Even a cursory glance at recent tables of contents and titles of texts related to literary studies reveals how they have exploded in many new directions as a result of these unexpected connections and the fascinating opportunities they provide for enhancing the work of critics, readers, and theorists. 
In the humanities and social sciences, one major impetus has been the development of "cultural studies," which is not really so much a novel perspective or field of inquiry as it is acknowledgment of and testimony to the new importance attributed to the ways in which all human products and positions are ineluctably intertwined with their contexts.

Cultural studies and feminist studies have much in common, and geography rather surprisingly provides a set of concepts and vocabulary which facilitates linking both with literary studies. In this essay I propose to examine significant links among them and to apply those findings to two representative "local color" stories of nineteenth-century U.S. writer Kate Chopin, traditionally considered a "regionalist" author, in order to explore not only the ways in which the context is inscribed within these stories, but also strategies by which she and her female characters inscribe themselves within the literary texts and contexts, forging new identities and (re)claiming space both literally and metaphorically.

\section{Contextualizing Feminisms}

Feminism is as old as gender interaction itself, but as a movement in literary theory and criticism, it took form in the 1960s as part of the women's movement, which was itself part of a larger social-philosophical-political phenomenon which fomented human rights, respect for individualism and diversity, and freedom from hegemonic, institutionalized impositions of all kinds. Initially (in its early, white, middle-class version) feminism developed around the belief that we live in a patriarchal society which marginalizes women (originally dealt with as a homogeneous group) and which demands positive change. Following in the footsteps of Virginia Woolf's landmark A Room of One's Own, Simone de Beauvoir was among the first to explore this idea in her now classic concept of women as "the second sex." Other important early feminists included Germaine Greer, author of The Female Eunuch, Kate Millett, author of Sexual Politics, and Betty Friedan, author of The Feminine Mystique. Since then, feminism has continuously evolved in response to changing social context(s), constituents, and concerns. For the purpose of providing an overview (and at the risk of oversimplifying), generally speaking "First Wave" feminists tended to focus on political and legal rights, "Second Wave" on social equality, "Third Wave" on affirmation of gendered difference, and contemporary feminists on recognition and validation of diversified gendered subject positions. In fact, feminist theories and practices have now developed to the point that use of the plural form -feminisms- is not merely more accurate, but practically obligatory if one is to attest to the present state fairly. There have been two constants in this changing feminist panorama, however: first, the fundamental premise that gender is a significant factor in human subjectivity, and second, a holistic approach to that gendered subjectivity which invariably grounds it in context (although in a myriad of significantly different ways).

Feminists have always recognized -indeed, insisted- that selfhood is tied (in clearly Gordian knots) to cultural context. The early feminist slogan "the personal is political" acknowledges that fact by suggesting that the situations of our ordinary, everyday lives are bound to political (power) structures and social interactions. More importantly, with admirable simplicity, it articulates the crucial connection between the individual and the collective and thus between person and place: who and what we are is intimately related to (some would even 
say determined by) our specific cultural context. As social anthropologists, sociologists, linguists and psychologists have affirmed in diverse ways and on multiple occasions, we are culturally bound. Theorist Louis Althusser, among others, developed the concept of the social "subject" as constituted by the "ideological apparatuses of the State" in the sense that this person is "formed" by an acquired, imposed sense of personal position which responds directly to the "place" assigned by the hegemonic group of the society in question. In this way, the "subject" is not merely a member but also a product of his/her society. The word "subject" is also conscientiously employed as a replacement for the more traditional term "individual" because of the latter's connotations of free will and uniqueness, which are challenged by cultural materialists in particular and poststructuralists in general. Yet another explanation of "subject formation" is posited by in terms of psychological and linguistic development by Jacques Lacan, who sees the subject's entry into the symbolic order of language as crucial to construction of identity. In these theories, context plays an important role.

One of the key issues underlying such concepts of human subjectivity -and of particular importance to feminists- is that of agency, the degree to which an individual is both free to act and takes the initiative in acting, as opposed to reaction or inaction. Feminists see women's potential for agency in a patriarchal context as truncated at best, nonexistent at worst. Louise A. Montrose proposes that rather than juxtaposing hegemony and agency, it is more productive to view them as "mutually constitutive processes" in ways that acknowledge:

\footnotetext{
that social systems are produced and reproduced in the interactive social practices of individuals and groups; that collective structures may enable as well as constrain individual agency; that the possibilities and patterns for action are always socially and historically situated, always limited and limiting[....]Thus, [...]the term "Subject" is meant to suggest an equivocal process of subjectification: on the one hand, shaping individuals as loci of consciousness and initiators of action -endowing them with subjectivity and with the capactiy for agency; and, on the other hand, positioning, motivating, and constraining them within -subjecting them to- social networks and cultural codes that ultimately exceed their comprehension or control. (21)
}

These are all locational issues because they are connected to boundaries and positions between the personal and the collective, as well as among different collective sites. Feminists deal with these interstitial matters mostly in terms of gendered spheres, autonomy, marginalization, representation, voice, and, above all, identity.

\section{Feminist Geographies of Identity}

Geography becomes involved not only in the quite literal sense of gendered spaces, but more significantly in the less concrete sense of "identity politics" or "the geographics of identity," as it is often called. These terms were originally employed by "minority" groups of all types, not just women in general but also African-Americans (male and/or female), gays and lesbians, formerly colonized groups, immigrants, and Chicanos, to name just a few-in other words, any group which has found itself marginalized by exclusionary visions and policies. Feminisms intersect all these groups in their acknowledgement -shared by other cultural studies analysts- that social hierarchies are never restricted to a single factor (gender, class, or ethnicity, for example), but they differ from the rest in privileging gender 
differentiation as a crucial divisive issue in societies of the past and present. Contemporary culturalists sometimes refer to the "politics of containment" in demonstrating how hegemonic groups promote themselves and marginalize all "difference" in subtle but forceful ways. From a feminist perspective, this containment runs the gamut from very physical manifestations of restricted geographical place for women to much less tangible repercussions, such as how gender marginalization is internalized to the point where it influences women's psychological development and selfhood. Although this is not the time or place to develop that aspect, it goes without saying that there are a multitude of related positions on those issues also.

Terms such as "gendered cartographies" and "mapping gender" highlight the seminal connections between place and the gendered self. Critic-theorist Susan Stanford Friedman asserts that "identity is [...] unthinkable without some sort of imagined or literal boundary," at the same time that she recognizes that feminist concerns with women's place have not been static: "From an earlier emphasis on silence and invisibility, feminism has moved to a concern with location-the geopolitics of identity within differing communal spaces of being and becoming" (3). She argues for a reformulation of feminism in "locational" terms:

\footnotetext{
[...] the time has come to reverse the past pluralization of feminisms based on difference, not to return to a false notion of a universal feminism that obliterates difference but rather to reinvent a singular feminism that incorporates myriad and often conflicting cultural and political formations [....] The feminism in the singular that I advocate assumes a locational epistemology based not upon static or abstract definition, but rather upon the assumption of changing historical and geographical specificities that produce different feminist theories, agendas, and political practices[....] Locational feminism pays attention to the specificities of time and place, but [...] it is not parochially limited to a single feminist formation and takes as its founding principle the multiplicity of heterogeneous feminist movements and the conditions that produce them. (4-5)
}

As Friedman emphasizes, the idea that "women suffer the same gender oppression in all societies" is significantly different from the idea that all women suffer gender oppression; metanarratives which base feminist affiliation only on gender victimization "suppress understanding of gender's interaction with other constituents of identity" (5). She also rejects any significant distinction between "space" and "place" because she believes "any way in which we think about space is always a form of cultural construction" with specific meanings, rather than a "preexisting entity" (261).

Considerations of sameness and difference are key issues within feminist discussions of gendered identity and place. Henrietta Moore suggests that the term identity is itself contradictory in nature: "Thinking about difference entails [...] thinking about identity and/or sameness" (qtd. in Friedman 75). Friedman concurs: "identity requires a perception of difference from others in order for the recognition of sameness to come into play" (75). Massey posits a significantly gendered differentiation of place by asserting that the traditional concept of space is yet another example of masculine encoding. She demonstrates how issues of space tend to be debated in classically dualistic terms, beginning with place/space, where "place" represents the local, specific, and concrete, while space is theoretical, conceptual, disembodied. In a tradition dating as far back as Aristotle, the patriarchy has claimed the space of the abstract — of knowledge, spirit, disembodied essence-while the feminine has been assigned the place of the practical and the concrete. The issue becomes even more polemical when the masculine sphere is defined as the public and global and the feminine is 
consequently assigned that of the private and local. However, spatialized differentiation of identity is not necessarily perceived as fixed or even defined. Chantal Mouffe affirms: "we are in fact always multiple and contradictory subjects, inhabitants of a diversity of communities (as many, really, as the social relations in which we participate and the subject-positions they define), constructed by a variety of discourses, and precariously and temporarily sutured at the intersection of those positions" (qtd. in Massey 7-8).

Gendered geography has far-reaching implications. Its main significance for the purposes of literary studies is its perception of literature as a privileged site for encoding gender and inscribing self. Approaching a literary text from a perspective of feminist geographies entails examination of the personal and social space inhabited -whether ascribed or appropriated- by women in that text and the import of the same.

\section{Kate Chopin's Regions}

Kate O'Flaherty (1850-1904) was born in St. Louis, Missouri, and spent most of her life there, with the exception of a fourteen-year stay in Louisana, home of her husband Oscar Chopin. Although Chopin was well-known during the time she was publishing her works, she joined the ample ranks of forgotten female authors after her death and essentially remained there (in spite of Daniel Rankin's unremarkable biography of her in 1932) until she was "rediscovered" by Norwegian scholar Per Seyersted in the late 1960s and promptly embraced by feminist scholars and students in the U.S. She is now most known - and, indeed, has achieved canonical status- for her second (and last) novel, The Awakening; however, Chopin is also the author of nearly one hundred short stories, a play, and some poetry, as well as various essays and sketches, literary reviews, personal journals and letters, translations, and other nonfictional material. Chopin's professional writing career was built around her short stories, though, and literary anthologies and histories of the twentieth century (before her rediscovery) presented her, if at all, as a local color or regionalist writer, with very occasional inclusions of one of her "Creole" stories.

Kate Chopin was born into a large, well-to-do family and lived a fairly predictable life as a young society belle until the time of her marriage in 1870, with one exception: the death of her father in 1855 fomented both the authority and the influence of her mother, her grandmother, and especially her greatgrandmother, all of whom served as atypical (for that time) models of women's strength and independence. Until the time of her husband's death near the end of 1882, Chopin appears to have lived a conventional life as a wife and mother in New Orleans and Cloutierville, Louisiana, where they raised their family of five sons and a daughter. As a widow of independent means, Chopin stayed in Louisiana taking care of family affairs until 1884, when she and her children moved back to St. Louis. In the late 1880s, Chopin first began writing for possible publication, and her first story was published in the St. Louis Post-Dispatch in October, 1889. From that time until two years before her death, her stories appeared regularly, first locally and later in such well-known magazines of the day as Vogue, Youth's Companion, Century, and the Atlantic. Her first collection of stories, Bayou Folk, was published by Houghton Mifflin in 1894, and the second, A Night in Acadie, by Way \& Williams in 1897. Publication of her last short story collection, A Vocation and a 
Voice, was accepted in 1898 but did not appear in print until ninety years later. The Awakening, the story of a young wife and mother who abandons her family in search of autonomy and selffulfillment, was first published in 1899 and created a tremendous response, much of it very critical of Chopin's open treatment of female sexuality and self-assertion, although it was never banned, as a popular misconception holds. Health problems prevented Chopin from publishing regularly in the two years before her death.

Another common misconception about Chopin is that she took neither her writing nor herself as an author very seriously; however, Chopin scholars, especially Per Seyersted and Emily Toth, have unequivocally disproved this through thorough research of her public and private documents. The general public's misperceptions perhaps respond to a combination of factors. First, Chopin carefully nourished her privacy -in contrast to her prominent, lifelong socializing-, and exercised considerable discretion not merely with her public and her own family and friends, but even in her own diaries. Secondly, although Chopin herself propagated a public image of herself as a spontaneous writer who rarely revised her work, her letters and manuscripts reveal a "highly disciplined, ambitious writer whose aims sometimes conflicted with expectations for women, and especially for mothers" (Toth and Seyersted 131), the latter part of which hints at her possible motivation for so doing. Third, Chopin's writing style, as she freely acknowledged, is partially modeled after Guy de Maupassant, a French author whom she admired for his brevity and forthrightness, as well as his nonjudgmental and unsentimental depiction of reality, traits clearly deviating from the literary norms of that time in the U.S. Fourth, and perhaps most importantly, her publishers and reviewers tended to perceive her and to promote her as a children's author and local color writer, neither genre of which was accorded much prestige or seriousness of purpose -much less aesthetic value- during the last decades of the nineteenth century, although both enjoyed considerable popularity.

Local color and regionalist literature (taken as literary trends, rather than simply as types of literature) were both part of the larger literary movement called Realism, which flourished in the U.S. after the Civil War (1861-1865). Most literary historians see that timing as important, but they disagree about its possible significance. Some assert that local color and regionalist literature developed in response to the need to reaffirm the value and the heterogeneity of regional identities within a national whole, as part of the post-war healing process, while others see them as nostalgic, if doomed, attempts on the part of the authors to deny the changing realities of the newly fragmented, industrialized society by continuing to live in an idealized past. In either case, in the U.S. literary arena of the late nineteenth century, geography circumscribed both issues and opportunities. A further complication was the fact that in all cases, geographical matters were intertwined with gender issues. This was so in the first place because women writers unquestionably dominated the literary scene as bestselling authors-much to the disgruntlement of their male counterparts, as manifested in Nathaniel Hawthorne's infamous derogatory comment about that "damn'd mob of scribbling women." A second crucial connection lies in the fact that, from their beginnings, local color and regionalist literature was associated with women authors, to the extent that critics such as Michael Davitt Bell and Donna Campbell have asserted that the Naturalist movement at the end of the century emerged to counter the "feminization" of U.S. literature.

The alacrity and enthusiasm with which so many prominent women writers of the time—-such as Sarah Orne Jewett, Mary Wilkins Freeman, Grace King, and, of course, Kate 
Chopin — chose local color stories as their literary vehicle lends considerable credence to the possibility that they were indeed taking advantage of the space profferred by their particular juncture of historical and literary circumstances to advance personally and professionally. Greater academic opportunities and leisure time also contributed to a women like Kate Chopin exploiting authorship as a means of personal fulfillment and practical sustenance (although Chopin's situation was privileged in the sense that her inheritances allowed her considerable financial stability). The fact that local color writing emphasized -indeed, revolved around- the mundane lives of ordinary people (mostly females) described in realistic detail provoked Frank Norris's famous dismissal of such literature as a "tempest in a teapot"; however, such traits also facilitated its grasp by literary novices in general and lent itself to the analogous limitations circumscribing the lives of these women authors.

What remains a matter of speculation in Chopin's case is her motivation for writing almost exclusively about Louisiana, especially because her professional writing began after her return to St. Louis. Chopin scholars have frequently suggested that Louisiana's exotic mixed population might have simply interested her more. Another possibility is that she might have believed that subject matter would be of greater interest to her potential reading public. Or perhaps she chose Louisiana because it had the advantage of being physically removed from her present habitat, particularly since she tended to model characters and situations on those from her own life. However, there may have been more subversive reasons involved. Perhaps the very "foreignness" of the Creoles and Acadians allowed her to explore the "dangerous" nether regions of her characters' minds and hearts more freely, exploiting their differences while maintaining authorial distance. This is an especially compelling possibility considering Chopin's interest -indeed, insistence- on exploring nontraditional attitudes and behavior in her stories. For example, in "Athénaise," a young bride leaves her husband because she feels trapped; "The Storm" (which was never published during Chopin's lifetime) describes an explicit sexual encounter between two former lovers who are now married to others, and which ironically benefits all the members of both families; "The Story of an Hour" deals with a woman's unexpected sense of relief and freedom upon hearing of her husband's death; "Fedora" contemplates a possible lesbian encounter. There is a clear progression in the contents of Chopin's writing from her early, much more traditional subject matter to increasingly subversive topics, characters, and attitudes, mostly in the guise of surface regionalism. In any case, there is no question that Kate Chopin conscientiously pursued personal expression and professional stature through her "regionalist" short stories.

\section{5. "Beyond the Bayou": The Contained Self}

"Beyond the Bayou" is one of Chopin's earliest stories, written in 1891, but first published in 1893 in Youth's Companion, then as part of Bayou Folk in 1894. Bayou Folk received national attention and was reviewed over one hundred times, most of which described the twenty-three stories as local color tales from Louisiana which were "quaint," "agreeable," and "charming." The simplistic nature of these comments is striking when one considers, for example, that "In Sabine" - the story of an isolated battered wife who could not even write for help because she was illiterate, but who was "saved" by the arrival of an 
unexpected guest who sweeps her away— was described as "full of humor" (Toth 1999: 149). Also, apparently few, if any, reviewers were aware that Chopin took some liberties with her Louisianans as well, placing Acadians (refugees from Nova Scotia in the mid-1700s who had populated southern Louisiana, bayou country) in her writing about the Cane River (Natchitoches Parish) country in northwest Louisiana, whose white residents were almost exclusively "Creole," descendents of immigrants who came directly from France. The fact that most of her stories deal primarily with the lives of the women there responds to more than the local color tradition of women writing about women's lives, however; it is a clue that Chopin was exploring more profound topoi than the landmarks of physical place.

In Space, Place, and Gender, Doreen Massey asserts that "space [is] constituted out of social relations," thus emphasizing the social role played by place: "the social relations of space are experienced differently, and variously interpreted, by those holding different positions as part of it" (2-3). Massey asserts that the traditional concept of space as fixed corresponds to a desire to see identity as stable:

\footnotetext{
It is a view of place as bounded, as in various ways a site of an authentiticty, as singular, fixed and unproblematic in its identity. It is a conceptualization of place which rests in part on the view of space as stasis.

[.... The identities of place are always unfixed, contested and multiple. And the particularity of any place is, in these terms, constructed not by placing boundaries around it and defining its identity through counterposition to the other which lies beyond, but precisely (in part) through the specificity of the mix of links and interconnections to that "beyond". Places viewed this way are open and porous.

All attempts to institute horizons, to establish boundaries, to secure the identity of places, can in this sense therefore be seen as attempts to stabilize the meaning of particular envelopes of space-time [....], to impose the meaning to be attributed to a space, for however long or short a span of time. (5)
}

This is of particular importance in looking at the labelling of "local color" as a "women's movement and the perceptions of "local color" as "limited" and "inferior" literature. These juxtaposed perspectives of space -static and closed vs. dynamic and multiple- lead to two significantly different readings of "Beyond the Bayou."

"Beyond the Bayou" is the story of Jacqueline, better known as "La Folle" ("the foolish one"), an exslave in her late thirties who "had been frightened literally "out of her senses" " as a child by seeing their master, P'tit Maître-badly wounded in Civil War fighting - appear suddenly at their cabin. From that time on, she refuses to leave her home turf until the day the master's ten-year-old son, whom she loved dearly and called Chéri, accidentally shoots himself while hunting near her cabin. In spite of her "extreme terror" of crossing the bayou to the plantation manor, her love for the boy compels her to take him home, and the story ends with both characters clearly on the mend. If the reader is looking for nostalgic affirmation of an antebellum southern lifestyle, "Beyond the Bayou" becomes the story of an exslave whose unconditional love for her white masters leads her to put their wellbeing before her own, a comforting reinforcement of a social caste system based on wealth and race and an exaltation of traditional feminine (motherly) love, set in a site remarkably unchanged by the passage of time (except for a little slave girl's lost innocence due to the cruelty of war), considering the fact that the war had taken place a generation earlier.

The story clearly lends itself to a traditional "local color" reading because setting is given a very privileged role, going far beyond a simple background for action to developing 
character, generating plot, and suggesting theme. The time is explicitly post-Civil War, but the situation at the plantation, Bellissime, seems to have changed very little. La Folle dwells "alone in her solitary cabin, for the rest of the quarters had long since been removed"; however, the workers have simply been moved to "the new quarters" across the fields, as clarified when "the old black mammy," Tante Lizette, goes to tend La Folle during her illness. Meanwhile, La Folle continues to make "her patch of cotton and corn and tobacco like the best of them," which suggests that the former slaves continue to work their little plots of land as they always had, for personal subsistence. On the Saturday afternoon of the hunting accident, the fields were deserted because the "men had flocked to a neighboring village to do their week's trading, and the women were occupied with household affairs." The men and women referred to here, of course -although it is never specified-are the exslaves, the fieldhands and their families. P'tit Maître is simply described as a "middle-aged man, with a family of beautiful daughters about him," who "sat with his family and guests upon the gallery," and his wife's only other appearance is when she opens the door the next day and reports to La Folle (in standard English) what the doctor has said. It is not the plantation owners' lives which are presented as exotic or intriguing, but those of the workers.

The language of those workers is one of the principal characteristics defining both them and their origins. They speak their own dialect, a mixture of equally dialectical versions of French and English. When La Folle finds the wounded Chéri, who claims he is dying, she responds: "Non, Non! Put you' arm 'roun' La Folle's nake, Chéri. Dat's nuttin'; dat goin' be nuttin'." The omission of initial and final sounds in some words, the substitutionscharacteristic of black vernacular--of " $d$ "(in "dat") and " $t$ " (in "nuttin"”) for "th," the changed spelling of the word neck ("nake") to conform to the way La Folle would have pronounced it, are not only typical of that particular social group in that region, but also fundamental to local color writing. The story's dialogue is full of such examples, from the cries of the little girl who first sees La Folle that "La Folle done cross de bayer!" to La Folle's comment that "I come ax how my po' li'le Chéri to, 's mo'nin'." Linguistic difference as representative of larger social and cultural differences is also manifested in La Folle's use of French when talking to herself as she carries Chéri home: "P'tit Maítre! Venez donc! Au secours!" and "Bon Dieu, ayez pitié La Folle!" That Chopin was aware of the importance of such language use is apparent in the fact that the first printed version of this story included translations for these French phrases, but the book version did not.

Reinforcing this emphasis on local speech are references to the lifestyle and customs of the workers. For example, the woman who nursed La Folle during her illness did so by "concocting a tisane of fragrant herbs." And when La Folle sets off across the fields to the manor, the reactions of her peers reveal the boredom and relaxed rhythm of their lives: "Children, old men, old women, young ones with infants in their arms, flocked to doors and windows to see this awe-inspiring spectacle." Not only that, but their "simplicity" and naïvete are suggested in the next statement: "Most of them shuddered with superstitious dread of what it might portend." It is significant that La Folle's greatest pleasure seems to be her relationship with the master's family, especially the little son; she anticipates his arrival eagerly, cherishes the little black curls tied with a ribbon which he had given her, and spoils him with attention. The only other mention of joy in La Folle's life is the cattle: "she loved these dumb companions well, and like to feel that they were there," which reinforces the timeless, pastoral 
qualities of the setting (another staple of local color fiction). Her emotional life still seems to revolve around the family, in spite of her apparent isolation and status as exslave. When "Old Mis" [P'tit Maître's mother] died, La Folle had stood on "her side" of the bayou, "wailing and lamenting." These customs are contrasted with the behavior of the white masters, whose reaction to La Folle's unexpected appearance is not even recorded and who call upon the doctor for medical care.

The contrast is exquisitely implicit in the ambiguity of the title: "beyond the bayou" is used to refer to both sides of the bayou, and depends on which side the speaker is viewing. La Folle tells P'tit Maitre's children "wondrous stories of things that always happened 'yonda, beyon' de bayou'," and the narration states that "of the world beyond the bayou she had long known nothing, save what her morbid fancy conceived." But the narrative perspective (and language) is definitely from the manor side of the bayou, a spectator's gaze observing, with almost patronizing enjoyment, the peculiarities of a "different" cultural group. In Cultures of Letters, critic Richard Brodhead has suggested that such viewing responds to the fact that regionalist writing is closely related to the nineteenth-century development of leisure travel and summer vacationing as measures of class distinction. Obviously, traveling as novelty and as entertainment was the privilege of the upper classes, and local color writing -especially considering the prestigious magazines in which it tended to be published and the projected audience- fed into that trend, allowing readers the vicarious thrill of exotic places and enhancing their sense of superiority. The consistent importance given to descriptive detail is a fundamental element of this "local other," for clearly "local color" and "regional" fiction are not written for the inhabitants of those places, but rather projected toward those unfamiliar with the area.

In "Beyond the Bayou," the physical description of the setting both opens the story and establishes the sphere of the protagonist: "The bayou curved like a crescent around the point of land on which La Folle's cabin stood. Between the stream and the hut lay a big abandoned field [.... Through the woods that spread back into unknown regions the woman had drawn an imaginary line, and past this circle she never stepped." Added to these visual details are the internal visions of the protagonist: the childhood sight of P'tit Maître "black with powder and crimson with blood" had forever turned that world "beyond the bayou" red for La Folle, which was created that "fear of the world beyond the bayou, the morbid and insane dread she had been under since childhood." La Folle's "containment" in her limited sphere thus has multiple causes: there are the obvious but unmentioned differences of wealth, status, and race, resulting in clearly differentiated physical and social spaces which are assigned, understood and apparently unquestioned. There are also differences based on gender. La Folle is apparently free to work her particular patch of land, but like the other women, she is also responsible for the mending, laundry, housecleaning, and baking, as detailed in her Saturday chores, while the working men are in town doing the trading and the "gentlemen" in this story are busy with such activities as fighting wars, playing host, hunting, or being doctors. The fact that there is so little detail related to the male activities in the story could suggest that readers would be readily familiar with them, to the point that it becomes unnecessary to even mention them. It could also be a subtle strategy for emphasizing Chopin's concern with her female protagonist's life.

One crucial aspect of this life is the degree to which La Folle's containment is selfinflicted and voluntary. She chooses to isolate herself from the larger world -even just the world of the plantation-, perhaps because she is unable to conquer her fear, but perhaps 
because it affords her an independent, if lonely, life. For while La Folle's fear is described as "her only mania," one which literally and figuratively separates her from all the others in that place, and her early experience as frightening her literally "out of her senses," she is clearly not "crazy," in contrast to the protagonist of another of Chopin's "regionalist" story, "La Belle Zoraide," whose loss of a child results in madness. La Folle organizes her activities and supports herself, and her free access to the manor children is evidence that she is not considered potentially dangerous by anyone. And although it is possible to argue that her literal crossing of the bayou, with the parallel crossing of the psychological barrier, was forced upon her by Chéri's cries for help, the fact remains that ultimately La Folle does make a conscious choice to move beyond her self-imposed boundaries. The bayou itself is a classical "interspace," a border between La Folle's world and the outside world, a space of flux, represented by the variable ebbing and flowing of the bayou waters. At times the bayou forms an impassable barrier; when low, even the little children can cross it with no problem. Thus, the act of crossing the bayou constitutes a "state of liminality," defined by Victor Turner as "that moment and place in which an individual, separated from society, comes to be "betwixt and between the positions assigned and arrayed by law, custom, convention and ceremonial"' (Peterson 39). Not only is La Folle physically transgressing her self-defined limits, transforming the bayou into a "site of struggle," but also she is voluntarily releasing herself from her self-proclaimed exile.

The descriptive details which accompany the transgression of that spatial barrier vividly highlight that a transformation is indeed taking place. However, it is not immediate; the first crossing of the bayou leads La Folle to lose consciousness: "Then the world that had looked red to La Folle suddenly turned black —like that day she had seen powder and blood." It becomes a near-death experience, a psychological netherland paralleling the physical liminality of the bayou. Once surpassed, she is quite literally another person: "She arose, calmly, as if no tempest had shaken and threatened her existence but yesterday. [.... S]he quitted the cabin and walked across the old familiar field to the bayou's edge again. She did not stop there as she had always done before, but crossed with a long, steady stride as if she had done this all her life." Her personal transformation is paralleled by the changes in her physical surroundings: "a field where the white, bursting cotton, with the dew upon it, gleamed for acres and acres like frosted silver in the early dawn"; the workers' cabins "that yesterday had sent a clamor of voices to pursue her, were quiet now" and "[o]nly the birds were awake, and singing their matins"; the "broad stretch of velvety lawn [...] was delicious beneath her tread"; "those perfumes that were assailing her senses" came from "the thousand blue violets that peeped out from green, luxuriant beds [...] showering down from the big waxen bells of the magnolias"; "[t]here were roses, too, without number" and "right and left palms spread in broad and graceful curves." In other words, "all looked like enchantment beneath the sparkling sheen of dew," a fitting image of renewal.

The metamorphosis culminates when she (appropriately) ascends to the top step of the manor's veranda and "caught sight of the river, bending like a silver bow at the foot of Bellissime" and "[e]xaltation possessed her soul." Until that time, La Folle has had control of her life to a certain degree, within physical, self-imposed territorial limits and less tanglible, socially ascribed boundaries. Now, however, no longer confined to those circumscribed terrains, she charts new territories which are both literal and psychological: "A look of wonder 
and deep content crept into her face as she watched for the first time the sun rise upon the new, the beautiful world beyond the bayou." This new world is not merely one which is opening up to her, but one to which she has constructed the portal herself. Having expanded her claim to agency, she now appropriates new space. When Chéri's mother tells La Folle that he is asleep and asks if she will come back later, La Folle emphatically responds to the contrary and states her intention to wait there, feeling bound no longer by unarticulated racial and social constraints. As she abandons her condition of "otherness," she concomitantly trespasses the sphere of "elsewhereness," not merely claiming but, indeed, proclaiming her power to define herself on her own terms.

From the perspective of feminist geography, "Beyond the Bayou," as its title subtly suggests, encompasses much more than a local color story of an exslave's devotion or a reassuring tale of feminine nurturing: its sphere is the contested space of female agency, its landscape the cultural conditions which either constrain or empower social and psychological sites of self-inscription.

\section{6. “Désirée's Baby": The Exiled Self}

"Désirée's Baby" was written in late 1892 and was first published in Vogue on January 14, 1893, and again as part of Bayou Folk. It is one of Chopin's best-known and most frequently anthologized stories, which partially explains both her traditional reputation as a local color author and the traditional reading of this story as a fine example of regionalism. Like "Beyond the Bayou," the story deals with geographic ideology, mapping spheres according to coordinates of gender, social status and race even more explicitly than the previous tale. However, like most of Chopin's "regionalist" writing, there is more than what appears on its literary surface; in this case, the fictional topoi very clearly define the zones of cultural practice while subversively challenging that social definition of women's space and place.

In "Désirée's Baby," the actual topography of the setting is not nearly as important as it is in "Beyond the Bayou," but the social cartography is crucial. The story takes place at the Aubignys' plantation, L'Abri, in Louisiana, a place described as "sad looking" enough to cause Désirée's mother to shudder upon seeing it: "The roof came down steep and black like a cowl, reaching out beyond the wide galleries that encircled the yellow stuccoed house. Big, solemn oaks grew close to it, and their thick-leaved, far-reaching branches shadowed it like a pall." It takes place at a time when slavery was still legal, and racism darkens the inhabitants' lives just as the branches do the manor: "Young Aubigny's rule was a strict one, too, and under it his negroes had forgotten how to be gay [...]." Désirée's own situation parallels the previous two; not only was she an orphan who had been discovered as a baby "lying asleep in the shadow of the big stone pillar" of the Valmondés' manor, but as a young wife her life is completely overshadowed by her husband. These concentric layers of descriptive details function as geographical markers leading to the key site of struggle in this story: gender space, both literal and figurative.

The relationship between Armand Aubigny and Désirée is hierarchical for a variety of reasons and in a variety of ways. First of all, Désirée, who is never identified explicitly by a last name, is an orphan, apparently "purposely left by a party of Texans, whose canvascovered wagon [...] had crossed the ferry that Coton Maïs kept, just below the plantation." The 
significance of this condition is made clear when Armand falls madly in love with her and, in spite of the "practical" concerns voiced by her foster father, declares he does not care about her "obscure origin" or the fact that "she was nameless" because "he could give her one of the oldest and proudest [names] in Louisiana." As an orphan, Désirée is literally "nobody" and must occupy a marginalized space. In this region social status and power are closely related to family name and wealth; thus, as soon as Armand chooses Désirée, he "ordered the corbeille from Paris," and they were married as soon as it arrived. Armand himself had been born in France and returned to Louisiana at the age of eight, "old Monsieur Aubigny having married and buried his wife in France, and she having loved her own land too well ever to leave it." When the child of the story title is born, Armand is "the proudest father in the parish [...] chiefly because it is a boy, to bear his name [...]," at least according to Désirée. Clearly, the most to which Désirée can aspire is marriage to a man of importance like Armand, which gives her vicarious social status and a defined place in her society by means of association.

A second major criterion of differentiation is that of race. Not surprisingly, Armand shares the racism prevalent among slave owners, not only exploiting his slaves for labor, but also using them as scapegoats according to his moods. The arrival of his son assuages his treatment of them, the birth having "softened [his] imperious and exacting nature greatly"; Désirée tells her mother that Armand "has n’t [sic] punished one of them -not one of themsince baby is born." The slaves are omnipresent in this plantation lifestyle, from the field workers to the household help to the little quadroon boy who fans the baby with peacock feathers while he is sleeping. It is precisely the proximity of these two children that sparks Désirée's comprehension of what was "in the air menacing her peace" and causing a dramatic change in her husband's behavior of late. There was "an air of mystery among the blacks" and then "an awful change in her husband's manner, which she dared not ask him to explain": he spoke to her, if at all, "with averted eyes," "absented himself from home [,] and when there, avoided her presence and that of her child, without excuse." Most tellingly, "the very spirit of Satan seemed suddenly to take hold of him in his dealings with the slaves." When Désirée sees the resemblance between their son and the slave child, she begs Armand for an explanation, to which he replies, "It means that the child is not white; it means that you are not white." Désirée rejects that explanation, citing her bown hair, gray eyes, and white skin, but Armand is unswerving in blaming Désirée and her unknown origins for their biracial child and feels totally justified in his rejection of them because of it. The story ends ironically, with Armand's discovery of an old letter from his mother thanking God "that our dear Armand will never know that his mother [...] belongs to the race that is cursed with the brand of slavery," which underscores the complexity of interracial relations at that time and its profound repercussions. The racial coordinate on this particular social map is of crucial importance.

However, gender issues are ultimately the crux of this story, as the final scene between Désirée and Armand manifests. Armand's automatic attribution of blame to Désirée is surely related to her "obscure origins," but it also responds to his arrogance and inability to accept even the possibility of any wrongdoing or imperfection on his own part. The same passionate intensity which drove him "headlong over all obstacles" and led him to marry her is not significantly different from the incredible coldness with which he rejects her later; Désirée "called to him, in a voice which must have stabbed him, if he was human. But he did not notice [...]." She is little more than a possession to him, as represented by his burning of her corbeille, 
along with the baby's belongings, after they leave. Totally indifferent -if he is even aware- of his wife's suffering, Armand "no longer loved her, because of the unconscious injury she had brought upon his home and his name." He uses Désirée just as he does his slaves: "He thought Almighty God had dealt cruelly and unjustly with him; and felt, somehow, that he was paying Him back in kind when he stabbed thus into his wife's soul." Although contemporary readers might have difficulty understanding Désirée's unquestioning acceptance of her husband's judgments, her behavior is consistent with her previously established total dependence upon Armand: "When he frowned she trembled [....] When he smiled, she asked no greater blessing of God." In this gendered terrain, Armand is obviously the center, and Désirée the marginalized "other."

Most readers resignedly assume that Désirée's decision to disappear with her child into the "deep, sluggish bayou" (from which "she did not come back again") is as inevitable as it is pathetic. However, Chopin employs several narrative strategies which subtly allow for more subversive conclusions. Some feminist critics have asserted that Désirée's choice is not merely a noble one but actually a victory, for two reasons. First, it is a manifestation of agency in the sense that Désirée herself chooses her destination and her destiny, within the limitations imposed by her society. Second, they see death as a more dignified choice than total subservience or marginalization. Désirée's literal departure from the plantation, even if viewed as voluntary exile, is also a decision ultimately made by Désirée herself to leave behind her charted position of "otherness." Chopin characteristically does not impose a value judgment on her protagonist's actions, but rather leaves it to each reader to take a personal position. This provides a degree of lack of closure to the story, in spite of its seemingly tightly constructed plot, a technique frequently employed by women writers to write "beyond the ending," in Rachel du Plessis's phrase. Another strategy used by Chopin in this story to undermine the gendered mapping of this society -and its "regionalist" surface- is the fluctuating narrative perspective. Although the dominant use of an omniscient narrator substantiates the apparent transparency of the narration, occasional insertions of a third person perspective not only allow the reader to know Désirée's thoughts and feelings in a more immediate, compelling manner, but also subtly privilege her position in this tale. Armand is clearly the focal point in terms of status and power, perhaps even plot, but Désirée is the subject of the story-not Armand, not their baby, and not racism. And as a character, Chopin constructs her as a subject, not an object, by dignifying her not only as the active center, but as the real story itself. "Désirée's Baby" is not merely a local color story of life in patriarchal, racist Louisiana, but, more importantly, a chronicle of one woman's inscription in that social space.

\section{Locating Gender on Chopin's Literary Maps: Conclusions Not Included}

It would be both paradoxical and counterproductive, not to mention presumptuous, to claim any finality in the conclusions to this (or any other) examination of how Chopin charts women's subjectivity in her "regionalist" stories. In part this is so because every analysis is itself inscribed, and to some extent prescribed, in the reader's own "protocols of reading," as Robert Scholes has called them. These maps for reading provide the logistical (and epistemological) tools for decoding texts, determine the mental moorings, and prioritize the 
coordinates employed in that deciphering. Although to some degree they are unconscious, readers also make choices in employing specific perspectives and methodologies in their readings, all of which combine to make the conclusions nearly infinite in their possibilities. Thus, the reading process itself, which includes literary understanding, is necessarily contextualized. Beyond this, however, from the perspective of geographies of identity, resides a concept of human subjectivity which (happily) refuses to remain static and which is always an agent of its own fluctuating definition. Gender, as a culturally constructed component of subjectivity, is equally dynamic; it is formed and transformed by the continuous interaction between self and context. For that reason, to speak of "locating gender" is to state the obvious, since gender can never be divorced from its context. Identifying the position(s) of the gendered subject implies recognition and acknowledgment of the ways in which that subject is inscribed in the cultural spaces of being and becoming as determined by a given place. Fixing those positions permanently is an impossibility.

In choosing to write "regionalist" stories, Kate Chopin made a conscious decision to channel both her professional aspirations and her personal agenda through a type of writing already well-established as "literature" and readily accepted by the reading public of the late nineteenth century. Her personal and professional objectives were closely intertwined: becoming a respected, published author with a national reputation was a vehicle for selffulfillment. It not only contributed to a purposeful, gratifying existence but also provided a venue for exercising her voice on a scale beyond her private diaries and her well-known "Thursday salons" in St. Louis. It is in this fictionalized voice, which in so many ways parallels her personal life, that Chopin's profound awareness of and fascination with the junctures of gendered subjectivity and society become apparent. Through her choices of characters, subject matters, settings, and style, Chopin appropriates literature as a site of personal inscription and as a diagram of social terrains. Through her literary representations of gendered space, she plots surface realities and constructs alternatives beneath those surfaces. As Adrienne Rich affirms, "a place on the map is also a place in history"-a positioning of the self as a subject. Chopin trespasses the literary and gender limits of her time and place, and maps new geographies of identity which resonate beyond the local and the immediate.

\section{Bibliography}

Ammons, Elizabeth. 1992. Conflicting Stories: American Women Writers at the Turn into Twentieth Century. New York: Oxford UP.

Baym, Nina. 1981. Introduction. The Awakening and Selected Stories. By Kate Chopin. New York: Modern Library.

Bloom, Harold (ed.). 1987. Kate Chopin. New York: Chelsea House.

Booth, Alison (ed.). 1993. Famous Last Words: Changes in Gender and Narrative Closure. Charlottesville: UP Virginia. 
Boren, Lynda S. and Sara deSaussure Davis (eds.). 1992. Kate Chopin Reconsidered. Baton Rouge: Louisiana State UP.

Brodhead, Richard H. 1993. Cultures of Letters: Scenes of Reading and Writing in NineteenthCentury America. Chicago: U of Chicago P.

Campbell, Donna M. 1997. Resisting Regionalism: Gender and Naturalism in American Fiction, 1885-1915. Athens: Ohio UP.

Chopin, Kate. 1969. The Complete Works of Kate Chopin. Ed. Per Seyersted. Baton Rouge: Louisiana State UP.

Davidson, Harriet. 1991. “In the Wake of Home': Adrienne Rich's Politics and Poetics of Location." Contemporary Poetry Meets Modern Theory. Ed. Antony Easthope and John O. Thompson. Toronto: U Toronto P: 166-94.

DuPlessis, Rachel Blau. 1985. Writing Beyond the Ending: Narrative Strategies of TwentiethCentury Women Writers. Bloomington: Indiana UP.

Ewell, Barbara. 1986. Kate Chopin. New York: Ungar.

Friedman, Ellen G. and Miriam Fuchs (eds.). 1989. Breaking the Sequence: Women's Experimental Fiction. Princeton, NJ: Princeton UP.

Friedman, Susan Stanford. 1998. Mappings: Feminism and the Cultural Geographies of Encounter. Princeton, NJ: Princeton UP.

Henderson, Mae (ed.). 1995. Borders, Boundaries, and Frames. New York: Routledge.

Higonnet, Margaret R. and Joan Templeton (eds.). 1994. Reconfigured Spheres: Feminist Explorations of Literary Space. Amherst: U Massachussetts P.

Inness, Sherrie A. and Diana Royer (eds.). 1997. Breaking Boundaries: New Perspectiveson Women's Regional Writing. Iowa City: U Iowa P.

Kaplan, Amy. 1988. The Social Construction of American Realism. Chicago: U Chicago P.

De Lauretis, Teresa (ed.) 1986. Feminist Studies/ Critical Studies. Bloomington: Indiana UP.

Levine, George (ed.). 1992. Constructions of the Self. New Brunswick, NJ: Rutgers UP.

Massey, Doreen. 1994. Space, Place, and Gender. Minneapolis: U Minnesota P. 
McDowell, Linda. 1999. Gender, Identity and Place: Understanding Feminist Geographies. Minneapolis: U Minnesota P.

Miller, J. Hillis. 1995. Topographies. Stanford: Stanford UP.

Montrose, Louis A. 1989. "Professing the Renaissance: The Politics and Poetics of Culture." The New Historicism. Ed. H. Aram Veeser. New York: Routledge: 15-36.

1990. Perspectives on Kate Chopin. Proceedings of the Kate Chopin International Conference, April 6-8, 1989. Natchitoches, LA: Northwestern State U.

Rich, Adrienne. 1998. "Notes Toward a Politics of Location." Literary Theory: An Anthology. Ed. Julie Rivkin and Michael Ryan. Oxford: Blackwell: 637-55.

Romines, Ann. 1992. The Home Plot: Women, Writing \& Domestic Ritual. Amherst: U Massachussetts P.

Simpson, Lewis P. 1997. The Brazen Face of History: Studies in the Literary Consciousness in America. 2nd ed. Athens: U Georgia P.

Toth, Emily. 1999. Unveiling Kate Chopin. Jackson: UP Mississippi.

Toth, Emily and Per Seyersted (eds.). 1998. Kate Chopin's Private Papers. Bloomington: Indiana UP.

Warren, Joyce W. (ed.). 1993. The (Other) American Traditions: Nineteenth-Century Women Writers. New Brunswick, NJ: Rutgers UP.

Zamora, Lois Parkinson. 1998. "Introduction: Moveable Boundaries-Public Definitions and Private Lives." Contemporary American Women Writers: Gender, Class, Ethnicity. Ed. Lois Parkinson Zamora. London: Longman: 1-31. 